\title{
Fictionalising interpreters: traitors, lovers and liars in the conquest of America
}

\author{
Victoria Ríos Castaño \\ University of Nottingham
}

Conquistadors' interpreters in America could be seen as mediators whose effort made possible the communication between Indians and Europeans. Yet, their very names are stigmatised as symbols of betrayal if and when they emerge as fictionalised figures in literature, political movements and popular culture. Columbus' interpreter is an outcast in both the New and the Old World. La Malinche is widely epitomised as Cortés' mistress and traitor of the Aztecs, although her identity has been re-evaluated as mother of the Mexican nation and feminist icon of Chicana writers. Felipillo, Pizarro's ill-reputed interpreter, is used in the Andean regions as a metaphor for corrupt politicians.

\section{Introduction}

In the era of the conquest and colonisation of the Americas, interpreters played an important role as a human means through which the forces of colonial power were imposed. The relative oblivion into which many of them have fallen is explained by a reluctance to admit to the presence of a third party that could cast a shadow on the importance of the powerful figures engaged in momentous negotiations. This reluctance may also be understandable given the low position most interpreters occupied in society as servants, slaves, members of inferior castes, and women (Delisle \& Woodsworth 1995: 244). Nevertheless, it is this very contrast between the interpreters' low social status and their possibility of interaction with the conqueror and his culture, that has captured public attention. In a few isolated cases interpreters have been drawn into the focus of popular culture and literature, albeit in a negative, stigmatised form. La Malinche, Conqueror Cortés' interpreter in the conquest of the Aztec empire, and Felipillo, Conqueror Pizarro's interpreter in the Inca empire, are two cases in point. They are the informants and mediators whose linguistic effort made possible the communication between Europeans and Indians during their first encounters. However, their closeness to the conquerors and the decisive role they played as instruments of domination of their own people have nurtured resentment and distorted their image. La Malinche and Felipillo have passed from history into the public imagination, with popular culture using them as symbols of treachery and vile behaviour in such a way that both have been turned into stereotypes of the liar, traitor and promiscuous lover. The extent of this creative process is quite remarkable, as may be illustrated by metaphors in the tabloid press criticising "Felipillo" Toledo's latest political 
agreement with President Bush, or defaming Salma Hayek as a "modern Malinche" reaping triumph in Hollywood. ${ }^{1}$

We may wonder whether such stereotypes are based on firm evidence. This article is an attempt to give some clues about how and why interpreters in the conquest of America have been perceived and described from the earliest dispatches of the colonisers to contemporary literary and political discourses. We shall focus on three interpreters who were active in three strategic areas of the period: the Antilles (Columbus), the Aztec empire (Cortés), and the Inca empire (Pizarro). ${ }^{2}$

\section{Diego Colón}

The point of departure for the fictionalisation of interpreting in the conquest of America is to be found in the historical dispatches, letters and chronicles in which the Europeans described their encounters and dealings with the local inhabitants who acted as interpreters. In his journal of the first voyage Columbus tells that after a few hours on the island of Guanahani (San Salvador) on October $14^{\text {th }}$, he could understand men and women from the tribe of the Arawaks who shouted "come and see the men who have come from Heaven; bring them food and drink" (tr. Jane 1930: 151). Similarly, Martín Pinzón, Captain of the Pinta, reportedly said that "he understood that this Cuba was a city, and that land was a very extensive mainland, which stretched far to the north, and that the king of the land was at war with the Grand Khan" (166).

However, this idyllic image of perfect communication between the two parties must have been far from the truth. Columbus' commissioned interpreter Luis de Torres, a convert who spoke Hebrew, Chaldean and Arabic, could not establish communication with the indigenes, and Columbus himself had to admit that his understanding was limited "as far as [I] could understand from the signs they made" (167). For one month the Admiral writes about the encounters he had with the people of the island whom he repeatedly described as well-formed, naked, gentle and in some cases wearing golden nose rings. Yet, his enquiries about the existence of gold and also about the Great Khan yielded no results. It is then that he came to a conclusion: "It had appeared to [me] that it would be well to take some persons, in order to carry them to the sovereigns, that they might learn our language, in order to discover what there is in the land and that, on their return, they might be tongues for the Christians and adopt our customs and the things of our faith" (169).

In the early stage of the conquest the recruitment method consisted mostly in capturing male Indians. On his arrival, on the $12^{\text {th }}$ October, Columbus employed this method on the island of San Salvador - known nowadays as the isle of Watlings in the Bahamas - where he took "by force some of the Indies, in order that they might learn and might give me information of that which there is in these parts" (261). Indian interpreters ful- 
filled a role of servants and were exposed to an immersion method to learn Spanish. After his second journey, Columbus wrote in a letter addressed to the Catholic kings in 1495: "there are now sent with these ships some of the cannibals, men and women and boys and girls. These their highnesses can order to be placed in charge of persons so that they may be able better to learn the language, employing them in forms of service" (tr. Jane 1930-1933: I, 88).

Early interpreters in America were not only expected to assist with conversations but also to provide information about their own land and facilitate the exploration of neighbouring areas. On the second journey Columbus' native interpreter, abducted on his first trip and baptised in Castile as Diego Colón (tr. Jane 1930-1933: I, 123), is said to have informed the Admiral that beyond Camaguey "lay Magón where all the people had tails, like beasts or small animals, and that for this reason they would find them clothed" (1930-1933: I, 138). ${ }^{3}$ This interpreter also had the responsibility of helping the Spaniards in their negotiations with other indigenes and their efforts to impress and indoctrinate them. Thus, Diego Colón explained to one of the caciques ('chiefs') of Cuba and his people "the things which he had seen in Castile and the marvels of Spain" and he told them "of the great cities and fortresses and churches, and of the people and horses and animals [...] and of the kinds of food [...] and of the festivals and tournaments which he had seen, and of bull-fighting" (1930-1933: I, 154). We lose track, however, of the fate this interpreter might have suffered afterwards, since in Columbus' letters on the third and fourth voyages he is never to be mentioned again. The Admiral makes brief remarks on other Indians he captured for interpreting purposes, and on the fourth voyage he recognises the impossibility of communication since "the villages, although they are very close together, have each a different language, and it is so much so that they do not understand one another any more than we understand the Arabs" (19301933: II, 102).

Due to the lack of information about those interpreters who accompanied Columbus and even travelled to the Old World, the reconstruction of their lives can be provided only through fiction. English journalist and translator Cedric Belfrage attempted to meet this challenge in his historical novel My Master Columbus (1961). As we shall see, his fictional account is based on information extracted from the log of the first voyage, letters and other documents related to later voyages.

The main character and narrator Yayael is Columbus' fictionalised personal servant who follows him on his four journeys. At the beginning of the novel, the Admiral shows his affection towards the young man when baptising him as Diego Colón, after his son's and brother's name. In historical reality Diego Colón would correspond to an interpreter whom Columbus captured in San Salvador and who travelled with him only during the first and second journeys (tr. Jane 1930-1933: I, 123). Belfrage draws on this historical information to present Diego as a competent Taino speaker who interprets for the Admiral in meetings with tribes such as the Ciguayos in Haiti 
and the Mariens and the Maguas in the Dominican Republic during the second and the third journeys. He reconstructs dialogues with native chiefs of these tribes, such as the Taino Guacanagari, and portrays Columbus' insistence on the need to ask for gold and tell the indigenes about Spain and their religion: "Colon [Columbus] explained through me [...] the marvellous world of the pink gods [the Spaniards] and Fray Buil gave his blessings" (Belfrage 1961: 84). However, Diego's linguistic competence lets him down during the fourth journey when the Spaniards reach Honduras, Nicaragua, Costa Rica and Panama. The interpreter then admits: "I could understand only a few words of the people's talk. This saddened me as I wanted to be of more use to Colon than rubbing him, emptying his pot and attending his clothes" (253).

Belfrage, through Diego's eyes, recreates the discovery told in reverse, from the viewpoint of the conquered. In his comments and explanations the fictionalised interpreter offers a personal version that contrasts with that of his master as conveyed by his journal, letters and other historical documents. For example, when disembarking in Cuba, Diego explains how the Spaniards "performed the same feather, tree, knee-bending and song magic as at Guanahani and the other islands" (Belfrage 1961: 28), which corresponds with what Columbus (tr. Cummins 1992: 94) described in his first voyage as "taking possession of this island for their Lord and Lady the King and Queen".

As an interpreter of cultures, Belfrage narrates how Diego's presence is required on several occasions by Fray Ramón Pané, who on the second voyage was commissioned by Columbus to record descriptions of the Taino culture. Diego tells us that Fray Pané "was struggling to find out what the people thought about creation, ancestors, gods [...], but my answers didn't clear up much of his confusion" (Belfrage 1961: 112).

Like Fray Pané, who wishes to understand the native religion and customs, Belfrage's Diego also strives to penetrate the mysteries of his master's culture, and finds difficulties in translating the world of the coloniser. He discovers that "the huge thunder-flutes poking their black noses out of the holes in the ship's sides" (25) are cannon and that the magic of the "Crosses hanging up all over the ship, some with a little carved man wearing a nagua [a skirt] on them" (31) is called Christianity. Through the book Diego's acculturation runs parallel with his love towards Columbus, whom he promises "to try harder to be civilised" (45), as well as with his growing devotion to the Spaniards' religion that he helps introduce: "Fray Buil instructed through me to talk to them about Christ and the Virgin" (82).

His role of mediator between the Spaniards who ask for gold and slaves, and the indigenes who undergo endless suffering places him in a difficult position. Thus, after having spent long periods of his life between 1495 and 1498 - the years of the second and the third voyages - with the family of his Magua wife, he realises that he has sold his soul to the evil Spaniards: "I was living with the people as one of them, but I was also the Spaniards" instrument to impose an end to their old life" (145). As a result there is no 
space for him neither in the Old nor in the New World. When the enslavement of the Maguas occurs, and he cannot assist those natives he had lived with and who now implore his help, he is cursed by them as a traitor, whereas without his master's personal presence he fears abuse from the Spaniards. He describes that during a solitary stroll around Santo Domingo two soldiers "knocked me on the floor and kicked my face, breaking some teeth" (247). His fate is bound to Columbus whom he eventually follows to Spain. However, the sudden death of the Admiral leaves him unprotected and after being found with a Jewish translation of the Bible he will be executed by the Inquisition. ${ }^{4}$

\section{La Malinche ${ }^{5}$}

Hernán Cortés' interpreter, immersed in the world of the Spaniards and the Aztec civilisation, interceded in favour of her master too. Cortés' soldier and chronicler Bernal Díaz in his True History of the Conquest of the New Spain narrates how in 1519 the young teenager Doña Marina was offered to Cortés, along with golden tokens as well as twenty other females, by the tribe of the Tabascans to commemorate a peace treaty (Díaz 1966: 54). Her life as an ordinary slave who ground corn and provided sexual intercourse would have continued, had it not been for her outstanding linguistic skills, as she spoke both Nahuatl, the language of the Aztecs, and Maya, the language of Yucatan. The absence of reliable biographical data previous to this first encounter with the Spaniards did not fail to foster a number of early fictionalisations of her origin.

Bernal Díaz, who claims to have known la Malinche, professed enormous admiration for her. In his depiction she emerges as a real Aztec princess and as an excellent woman "with a lot of temperament and who had power over all the Indians of the New Spain" (1966: 57). ${ }^{6}$ According to him, her father's death, her mother's remarriage and the subsequent birth of a new male inheritor combined to cause her misfortune. She was sold to some merchants and bought by the Tabascans with whom she learnt Maya. Yet, scholars such as Messinger (1991: 28) contend that the chronicler's affection and his tendency to fantasise reality made him draw on the chivalresque novel Amadis de Gaula in the reconstruction of her early life. In any case, it is extremely hard to assess the reliability of the information provided by the chronicler. As for his account of la Malinche as an interpreter, it remains a mystery whether Bernal Díaz could rely on a trustworthy informant to check her rendering in Nahuatl, a language he himself did not speak.

In the conquest of Mexico Cortés required the linguistic service of his Aztec slave and the missionary Fray Jerónimo de Aguilar, who had lived in Yucatán and spoke Maya. Both interpreters provided relay interpreting and used Maya as the pivot language: Fray Aguilar interpreted between Maya and Spanish, and Doña Marina between Maya and Nahuatl (Díaz 1966: 57). During the Spaniards' expedition towards Tenochtitlan, the capital of the 
Aztec empire, they were to be instrumental in attaining the double objective of the colonising enterprise: submission to both political and religious power. For instance, before reaching Tenochtitlan, they interpreted for Cortés in Tlaxcala "that if they [the caciques] did not come with the peace [...] we would go to kill them and destroy their lands" (1966: 107).

However, once la Malinche became proficient in Spanish and probably had become Cortés' lover, her role as personal adviser and interpreter of the conqueror cast a shadow on Fray Jerónimo. ${ }^{7}$ Bernal Díaz (1966: 135) declares that she was a cunning woman who could speak "with loving words" and imitate Cortés' tone, for in the city of Cingapacinga "Cortés told them many threats and our lengua Doña Marina knew how to make it understandable" (80). ${ }^{8}$ The chronicler mentions her direct interaction in diplomatic negotiations with Moctezuma as well as her denouncement of conspiracies against the Spaniards, and her success in persuading the Aztecs not to offer resistance to the invader. In Cholula, la Malinche informed Cortés that the Aztecs prepared an ambush to kill the Spaniards and when Moctezuma was seized, she said to him: "sir Moctezuma, I advise you to go with them [the Spaniards] since they will treat you with great respect, otherwise you will be killed" (169).

La Malinche remained silent during the next two centuries, as the Mexican dominant class showed no interest in resurrecting the pre-Hispanic past. But in the early 19th century, when this very ruling class was searching for a national identity and political independence, the revival of pre-Hispanic sources and images was in full swing. Mexicans renounced their Hispanic heritage and felt attached to the ancient Aztec empire. La Malinche was then recovered as a traitor and her identity was subsequently circumscribed by the patriarchal culture in a developing independent Mexico. She would be the female slave and lover who helped annihilate Aztec rulers and who became a master of thousands of enslaved Indians (Messinger 1991: 42f.). Xicoténcatl, published anonymously in 1826, was the historical novel that inaugurated this negative image. Messinger contends that this portrait established a landmark in the building up of her myth as a scapegoat, since two dramas on the same topic were performed in Mexico soon afterwards. La Malinche, the sole person responsible for Mexico's misfortunes, appeared as the anti-heroine in contrast to another female character, Teutila, who epitomised patriotism and Indian identity. La Malinche was identified with a Mexican Eve or a shrewd serpent, who in pursuit of her ambitions and desires became Cortés' lover. Contaminated by Spanish immorality, she suffered from falsehood, treachery and lewdness, an image that shaped the Mexican personification of treason and devotion to the foreign invader (Messinger 1991: 44f.).

It is precisely her sexual relationship with the conqueror that instigated further resentment coming from puritanical and patriarchal backgrounds. Her popular image evolved so as to eventually become that of a lustful monster or a repudiated raped woman known as la Chingada ('the fucked one'). In his essay "Los hijos de la Malinche" (the children 
of Malinche), Mexican Noble Prize writer Octavio Paz analyses the role that she had performed in the development of a special characteristic of Mexican identity known as Malinchismo. The interpreter embodies betrayal towards Mexicans, a sign of servile obedience to foreign cultures. La Malinche

has turned into a figure that represents the fascinated woman who is raped or seduced by Spaniards [...] The Mexican people do not forget her betrayal. She represents what is opened, what is fucked, in contraposition to our Indian men who are stoic, impassive, closed. (Paz 1950: 78)

The conflict between Mexican feelings of patriotism versus subjugation to foreign influence thus become gendered as a cultural confrontation between men and women. La Malinche is defined as a mythical mother, a Mexican representation of maternity, who has suffered the abject humiliation of being penetrated by a foreigner. Paz goes even further in associating her with a willing victim of rape, or with a devoted woman who is happy to satisfy Cortés until she is not needed anymore and gets dumped. Her children were to be tarnished by the terrible flaw of being malinchistas, in other words, Mexicans contaminated by foreign tendencies that mesmerise them and expose them to exterior influences.

This chauvinistic and extremely negative attitude towards the interpreter has been challenged by later generations of academics and feminist writers who have rehabilitated and glorified her, both as a Mexican and as a woman. In their quest for a national identity some authors have presented la Malinche as a symbol of the Mexican Mestizaje, as the mother of racial mixture. In this sense the Mexican writer and historian Sotelo Inclán deployed the mythical figure of Medea in his play Malintzin (Medea Americana) from 1957, so as to establish comparisons between both women and praise the interpreter as a Latin American symbol of racial mixing, a caring mother of the Mexicans. Both Medea and Malintzin - the Nahuatl name of la Malinche - are betrayed women who abandoned their people for love. Yet, the author's final judgement is in favour of Malintzin: "our Malinche is above the Asian women because she does not murder her son [the child she had with Cortés] and starts off the Mestizaje, our Mexican identity" (qtd. in Wurm 1994: 243). Similarly, the famous Mexican writer Carlos Fuentes in his play Todos los gatos son pardos ('all cats are grey') from 1970 presents Marina as the symbol of the colonial Mexico that was to be born from chaos and destruction; the mother of a new nation of mixed people. When giving birth she cries "go out, my child, to recover your land and your dreams. My child, white and dark, see if you can wash all this blood from the pyramids, from the swords" (Fuentes 1970: 173).

As to the feminist approach, the Mexican American writers known as the Chicana Movement have laid bare and denounced the patriarchal conceptions underlying the interpreter's prevailing image. For them, traditional images that mark boundaries in female-male relationships are derived from Cortés being served by la Malinche - a woman who draws on her sexual 
attraction, her linguistic competence, and her lack of scruples in trying to get what she wants. Mexican patriarchal society has used her figure as a scapegoat in an effort to sustain male power by treating women as sexual objects and inferior moral entities. The Chicana movement has adopted her as an icon to be identified with. They are educated women who have pursued careers in the United States and who have established a relationship with a non-Mexican man and his world. For this reason, they have been called vendidas ('sold out') and end up becoming an incarnation of la Malinche. They are violated by the Anglo-conqueror, an act that humiliates the Mexican race, and they betray their men and their people (Wurm 1996: 303f). Chicana writers such as poet and playwright Carmen Tafolla and writer and essayist Norma Alarcón have deconstructed La Malinche's paradigmatic characteristics of betrayal and victimisation, and recuperated the "maligned daughter" who was doomed to bridge the two cultures into which she was thrust. Far from denouncing her as a traitor, they assign to la Malinche the role of the native woman who negotiates before fighting and whose words bring peace and avoid bloodshed (Wurm 1996: 25).

Mexican writer Rosario Castellanos in the poem Malinche (1972) also explored the construction of the stigmatised figure and redeemed her from her faults. The poem reviews the association that Mexican culture had established between la Malinche and the legendary Aztec figure of La Llorona ('the wailing woman'), the sleepless woman who cries at night, regretting her sins and heralding calamities. In a first-person monolog of la Malinche as a young child, she tells the gloomy story of her early solitude. After her father's death, her mother soon remarried and sold her to a group of merchants. After her disappearance, her mother sheds false tears and cries inconsolably. La Malinche here emerges as a victim of her circumstances, as the one who is betrayed and victimised herself, instead of being the perpetrator. She distances herself from La Llorona as a forlorn child who does not cry for her sins but for herself, whereas she resembles the mythical figure because she is aware of the tragedy of the past that will project into her future:

I advance toward destiny in chains leaving behind all that can still hear

the funereal murmurs with which I am buried. (qtd. in Messinger 1991: 139)

Despite feminist efforts to portray Malinche as a symbol of oppression and an icon of a female revolution against patriarchal systems, popular fictionalisation still tends to reduce her to female stereotypes of lover and traitor. In fact, most current novels have portrayed the image of a romantic and passionate woman who betrayed the Aztecs to gain Cortés' favour. Among a range of novels which also include Margaret Shredd's Malinche y Cortés (1974), Kim Lefèvre's Moi, Marina la Malinche (1994) and Flor Romero's Malintzín, la princesa regalada (1999), ${ }^{9}$ I have chosen three others which clearly represent this stance. 
The Spanish writer Edward Rosset in his recent historical novel Malinche (2004) describes the interpreter as an intelligent and dynamic teenager who professed unconditional love to the conqueror and who enjoyed a passionate relationship with him: "she caressed his breast and his beard and whispered to him: [...] you are Marina's master, and the master of the child who will be born" (Rosset 2004: 209).

In Amor y conquista: la novela de Malinalli, mal llamada la Malinche ('love and conquest: the novel of Malinalli, wrongly named la Malinche') by the Mexican writer Marisol Martín del Campo (2002), far from being the cunning woman associated with the name la Malinche, Malinalli - another Nahuatl version of her name - is a suffering and passionate personality who throughout the novel remembers her first real love: Cortés' Captain Portocarrero. Despite her feelings for him, she also falls in love with Cortés and it is precisely this love which drives her to denounce the conspiracy of Cholula. On the very night of the massacre she describes how "we mixed our sweat [...], he and me, me and him, insensibly, until we reached the summit of our fever and cried at once" (Martín 2002: 119).

An extreme case can be found in La Chingada (1984) by Jane Lewis Brandt, in which la Malinche stands for a rather frivolous young woman who spends her life breaking hearts and being unfaithful to the conqueror. Eventually she becomes a zealous Christian. With her long dark hair, penetrating eyes and fine features, she captivates the son of her Tabascan masters, and no less than both the conquerors Arturo Mondrágon and Cortés. Even Aztec ruler Moctezuma expresses his attraction in one of his meetings with Cortés and tells her: "in other times I would have made you my concubine" (Brandt 1984: 255).

The image of la Malinche has also passed into other genres. See, for instance, José Clemente Orozco's painting "Cortés and Malinche" (1922) on the topic of the Mestizaje, or Rudolfo Anaya's lyrics for the opera La llorona ('the crying woman', 2002). Furthermore, she is represented in cultural traditions such as Mexican popular dances. These can be traced back to preColombian rites and can serve to illustrate the crucible of cultures that resulted from the Catholic influence after the conquest. Among many dances, Carmen Wurm (1996) describes the "Danza de la pluma" or "Danza de la conquista" ('dance of the feather', 'dance of the conquest') in commemoration of the Virgin in Oaxaca. There are two girls in it, one is named la Malinche and is dressed up in Indian attire and the other one is called Marina, dressed up in a Spanish colonial costume. The reason for this duplication is uncertain, although it might well be taken to symbolize the doubleness of the interpreter's situation.

\section{Felipillo}

A very singular commemoration of Felipillo, Pizarro's interpreter, is enacted in the North Western part of the Andean region of Peru every year on the 
21 of November. In the rite of the "Captura de Atahualpa" ("Atahualpa's capture') two groups of people are formed to represent the Inca ruler Atahualpa's followers and the Spaniards respectively. Felipillo, standing on the latter's side, is the object of insults and mockery. ${ }^{10}$ The popular performance is a clear indication of the malevolent associations that prevail in Peru, Ecuador and Bolivia as regards the figure of this interpreter.

Historians have presented different accounts of Felipillo's origin and his exact role in the conquest of the Inca empire. He is said to have been abducted by Pizarro in the Inca city of Tumbez in 1528 (Prescott 1931: 870). However, El Inca Garcilaso in his Royal Commentaries (1614) claims that Felipillo was "a native of the island of Puna, a man of very plebeian origin, young - for he was scarcely twenty two - and as little versed in the general language of the Incas as in Spanish" (Garcilaso 1966: 681). Cieza de León, the first historian of the Incas, speaks of him as an "interpreter and wicked traitor, [he] had fallen in love with one of [Atahualpa's wives], so much so that he was desperate to have her. While the lord [Atahualpa] was alive, he did not find courage - by entreaty, threat, or promise - to gain her" (Cieza 1988: 252).

Felipillo played a vital role in the negotiations between Atahualpa and the conquerors Pizarro and Almagro which led to the Cajamarca ambush in 1532, and the Inca's later execution. It is said that in the interview that took place between the Dominican Fray Vicente Valverde, Pizarro and Atahualpa "through the interpreter, [Atahualpa] understood everything well" (Cieza 1988: 211). Atahualpa's immediate reaction - he furiously and contemptuously threw the Bible to the floor - was understood as an act of sacrilege that quickly legitimised military intervention by the Spaniards. Cieza does not blame Felipillo for a biased misinterpretation and argues that Atahualpa flung the Holy Book into the air "without knowing what it was because to have understood it, they should have told him in another way, but the friars never preach around here" (ibid.). El Inca Garcilaso devotes a chapter of his history to the difficulty of interpreting Fray Vicente's speech accurately; he declares that Felipillo "often reversed the sense, but this was not done out of malice, but because he did not understand what he was interpreting and spoke it like a parrot. Instead of God three in one, he said God three and other make four" (Garcilaso 1966: 682).

Popular prejudice against the interpreter is the result of the role he would have played in the murder of the Inca ruler. Cieza (1988: 253) maintains that Felipillo spread the rumour that "Indian warriors [were] com[ing] from all parts, assembl[ing] on Atahualpa's orders to attack the Spaniards". Likewise Prescott (1931: 973) attests that Atahualpa was accused of adultery, idolatry and rebellion against the Spaniards after Felipillo had interpreted at his trial: "a number of Indian witnesses were examined, and their testimony, filtrated through the interpretation of Felipillo, received a very different colouring from that of the original".

Felipillo's fictionalisation in the realm of literature covers less ground in comparison with that of Malinche. Bolivian writer Néstor Taboada in his 
novel Angelina Yupanki (1992) makes a special reference to him and to Martincillo, Pizarro's other interpreter. Both of them would have been abducted by the conqueror in an expedition to the territory of Wáskar, Inca ruler Atahualpa's hated brother (Taboada 1992: 16). In this sexually very explicit account of the conquest, Felipillo emerges as a dissolute character who is driven by his sexual instincts. When his presence is requested by Pizarro in the assault of Cajamarca, he has disappeared in search of women. It is then that he meets Angelina, the young woman who gives the book its title and who happens to be Atahualpa's favourite wife. To obtain her sexual favours, he presumes on his condition of wallpan or interpreter of Pizarro, the Jatun Runa - a Classical Quechua term meaning 'big man': “My life is at the service of the foreigners. I am an official interpreter [...]. My friend is the king of a country called Spain, and also his wife the queen [...], there is no man as famous and well-considered as me" (27). Obsessed with Angelina, he hates and wishes to destroy her husband. Given his inclination to lie in order to fulfil his purposes, he disperses false rumours that involve Atahualpa in a conspiracy against the Spaniards; a betrayal that eventually condemns the Inca ruler to death. However, when Pizarro makes Angelina his lover, Felipillo admits "his hopelessness of regaining her, he cried at night

and during the day he discharged his fury on the backs of defenceless slaves" (82). His life, like that of Diego Colón in Belfrage's book, has a tragic end, since during an exploration of the South East he is found cut into pieces; some witnesses testify that he died crying the name of his beloved Angelina Yupanki.

Felipillo's image of an obsessed lover, as evoked by Taboada's recent novel and Cieza's historical document, has not prompted any popular fictionalisations of the interpreter as a traitor for love. In popular culture Felipillo has been reinvented as a traitor and a compulsive liar, but this image is mainly restricted to the traditionally male domain of politics. While in Mexico the term Malinchismo was coined to designate those who rapidly succumb to the foreigner, in Peru, Bolivia, Ecuador and Chile to call someone a felipillo implies the charge of political corruption and/or weakness in foreign affairs. In Peru, national newspapers and journals (e.g. El diario internacional) and citizens would typically apply the adjective to national and foreign politicians they regard as liars; that list would include Kofi Annan, who during his visit to Peru in November 2003 was described as Bush's felipillo, ${ }^{11}$ or Peru's current president Alejandro Toledo, nicknamed Felipillo Toledo due to the general discontent about his government's policies. The president's opponents have drawn on the figure of the interpreter to establish several resemblances between both: Toledo was educated in the United States, whereas Felipillo acquired his linguistic knowledge with the Spaniards; also, Felipillo pointed out the track for the conquerors to follow, the same strategy that Toledo is accused of adopting in his relationships with the White House. 


\section{Conclusion}

The early native interpreters became indispensable tools for the conquest, although often their relevance in linguistic and cultural exchanges has gone unrecognised or been vilified. At the time of the conquest, despite being engaged in decisive talks between conquerors and native rulers, their linguistic savoir-faire seems to have passed unnoticed as the conquerors were reluctant to acknowledge the role of servants, slaves and women. Willingly or not, they eventually turned into advisers and lovers who warned against conspiracies and told their own people not to revolt against the Spaniards. On the side of the conquered, they could wield a power they had never been favoured with in their native societies, while their role of intermediaries condemned them to be judged as betrayers.

The point of departure for the fictionalising of interpreters is to be found in the historical dispatches, letters and early chronicles of the conquest. Early images of the interpreters reflected common European perceptions of the New World as well as personal opinions. In this way, Columbus saw them as innocent Indians who needed to be civilised, whereas Díaz del Castillo transformed la Malinche's life into a version of Amadís de Gaula. The image of the interpreters was later adjusted to suit the needs of different ideologies or political movements. Thus, la Malinche has in the last two centuries served as a vehicle for Mexican claims of independence and national identity, or for the feminist rejection of a patriarchal society. Appearing in sundry literary genres, she sweeps down the catwalk of popular culture as $l a$ llorona ('the wailing woman'), the betrayer, the chingada ('the fucked one'), the lover, the Mexican Eve, or the scapegoat of Mexican chauvinism. But a character like Felipillo has inspired less ideological discussion and fewer romantic literary representations; he became the figure of the liar and the traitor in the political sphere. Interpreters as traitors, lovers and liars have thus transcended the context of the historical conquest of America, having been turned into mythical figures in the service of contemporary politics, ideology, literary and popular culture.

\section{Bibliography}

Anon. (1964 [1826]). Xicoténcatl. Antonio Castro Leal (ed.). La novela del México colonial. 2 vols. México City: Aguilar, vol. 1, 401-616.

Barreiro, José (1993). The Indian Chronicles. Houston: Arte Público Press.

Belfrage, Cedric (1961). My Master Columbus. London: Secker \& Warburg.

Brandt, Jane Lewis (1984). La Chingada. Barcelona: Plaza y Janés.

Cieza de León, Pedro (1988). The Discovery and Conquest of Peru (tr., ed. Alexandra Parma Cook \& Noble David Cook). Durham/London: Duke UP.

Cummins, John (tr.) (1992). The Voyage of Christopher Columbus. London: Weidenfeld and Nicolson.

Delisle, Jean \& Judith Woodsworth (eds) (1995). Les traducteurs dans l'histoire. Ottawa: les Presses de l'Université d'Ottawa/Éditions UNESCO. 
Díaz del Castillo, Bernal (1966 [1552-]). Historia verdadera de la conquista de la Nueva España. México: Porrúa.

Fuentes, Carlos (1970). Todos los gatos son pardos. México: Siglo XXI.

Garcilaso de la Vega, el Inca (1966 [1614]). Royal Commentaries of the Incas and General History of Peru. Part two (tr. H. V. Livermore). Austin/London: University of Texas Press.

Glanz, Margo (ed.) (1994). La Malinche, sus padres y sus hijos. México: UNAM.

Herren, Ricardo (1992). Doña Marina, la Malinche. Barcelona: Planeta.

Jane, Cecil (1930) (tr., ed.). The Voyages of Christopher Columbus being the Journals of his First and Third, and the Letters Concerning his First and Last Voyages. London: the Argonaut Press.

Jane, Cecil (1930-1933) (tr., ed.). Select Documents Illustrating the Four Voyages of Columbus: including those contained in R. H. Major's Select Letters of Christopher Columbus. 2 vols. London: The Hakluyt Society.

Karttunen, Frances E. (1994). Between Worlds: Interpreters, Guides and Survivors. New Jersey: Rutgers UP.

Lefèvre, Kim (1994). Moi, Marina la Malinche. Paris: Stock.

Martín del Campo, Marisol (2002). Amor y conquista: la novela de Malinalli, mal llamada la Malinche. México: Planeta.

Messinger Cypess, Sandra (1991). La Malinche in Mexican Literature. From History to Myth. Austin: University of Texas Press.

Padgen, A. R. (tr.) (1972). Hernán Cortés: Letters from Mexico. London: Oxford UP.

Paz, Octavio (1967). "Los hijos de la Malinche". El laberinto de la soledad. México: Fondo de Cultura Económica, 59-80.

Prescott, William (1931). History of the Conquest of Mexico; and History of the Conquest of Peru. New York: Modern Library.

Romero, Flor (1999). Malintzín, la princesa regalada. Bogotá: UNEDA.

Rosset, Edward (2004). Malinche. Barcelona: Edhasa.

Shredd, Margaret (1974). Malinche y Cortés (tr. Nicolás Pizarro Suárez). México: Diana.

Sotelo Inclán, Jesús (1957). Malintzin (Medea mexicana). México City: Tiras de Colores.

Taboada, Néstor (1992). Angelina Yupanqui. Marquesa de la conquista. Barcelona: Apóstrofe.

Wurm, Carmen (1996). Doña Marina, la Malinche. Eine historische Figur und ihre literarische Rezeption. Frankfurt am Main: Vervuert Verlag.

1 References to "Felipillo Toledo" in "Radio TV Continente" and "Ollanta" may be found on line at http://www.continente.nu/castellano/artklar/artikelpost.cfm and at http://www.ollantaprensa.tripod.com.pe respectively. An article on Salma Hayek as a modern-day Malinche can be read in The Sydney Morning Herald at http://www.smh.com.au (consulted 1.12.2001).

2 The character of la Malinche will require a somewhat more extensive discussion than the two others.

${ }^{3}$ This quote comes from the early historian Andrés Bernáldez, who in writing his History of the Catholic Sovereigns (c. 1513) would have used "certain papers" Columbus had left with him. We do not know whether this comment belonged indeed to the native interpreter or whether he wanted to please his master in answering to the imaginary world Columbus and Bernáldez expected to find in those territories.

${ }^{4}$ Other fictionalisations of the same character include the recent novel José Barreiro's The Indian Chronicles (1993), in which the interpreter Diego Colón writes 
a journal about the early contact and conflict between the indigenous people of the islands in the Caribbean and the Spaniards.

${ }_{5}$ Her name could derive from the Nahuatl Malinalli or from the Christian name of Marina, given by Cortés and adapted to Indian pronunciation. Malinche, coming from Malintzin, contains the reverential suffix -tzin, an indication that at the time of the conquest the Aztecs had great esteem for her. Cortés was also known as Malinche, from the Nahuatl Malintzine meaning 'master of Doña Marina' (Messinger 1991: 33). Nowadays she is known as la Malinche, although current authors also name her Marina (as Cortés did), Doña Marina (as Bernal Díaz did), or as Malinali or Malintzin.

${ }^{6}$ Unless indicated otherwise, translations of Spanish quotations are my own throughout.

7 In 1522 the interpreter gave birth to a child who was recognised by the conqueror (Messinger 1991: 38).

8 It may surprise us that Cortés, as Columbus before, uses the term lengua ('tongue, language') to refer to his interpreters. We are tempted to infer that this usage, albeit common in $14^{\text {th }}$-century Spanish, implies an instrumental reduction of the interpreters' task. Although interpreters were indispensable tools to the colonising enterprise, they are treated as objects and the actual data we have seem to confirm such an attitude. Cortés, for example, declined to recognise them officially as relevant. $\mathrm{He}$ briefly refers to la Malinche in Letter two as "my interpreter, who is an Indian woman from Putunchan [Tabasco]" (Padgen 1972: 73) and in Letter five to King Charles V as "Marina, who travelled always in my company after she had been given to me as a present with twenty other women" (Padgen 1972: 376).

9 Shredd portrays the interpreter as a practical woman who fears Cortés and longs for freedom. Lefèvre uses her relationship with Cortés to delve into the mixing of cultures and its negative aspects. Romero recreates through la Malinche's eyes the conquest of Mexico and represents her as a sensible woman who loved both Cortés and her people.

${ }^{10}$ See http://travel.peru.com/travel/idocs/2002/10/31/DetalleDocumento_53622.asp.

${ }^{11}$ See comments at http://www.eldiariointernacional.com (consulted 13.12.2003) or at http://www.chileradio.cl (consulted 12.08.2003). 